\title{
Indium Tin Oxide Nanocomposites - Green Synthesis, Characterization, Morphology and Optical Properties Using Almond Gum
}

\author{
Battula Shanti Sree ${ }^{1}$, Yaramma Aparna ${ }^{1,2, *}$, Tadiboyina Anil Babu ${ }^{3}$ (D), Narasipuram Venkata Krishna \\ Prasad $^{3}$ (D), Bommaraju Srinivasa Rao ${ }^{4}$, Kanchana Latha Chittury ${ }^{5}$, Dachepalli Ravinder 6,* (iD)

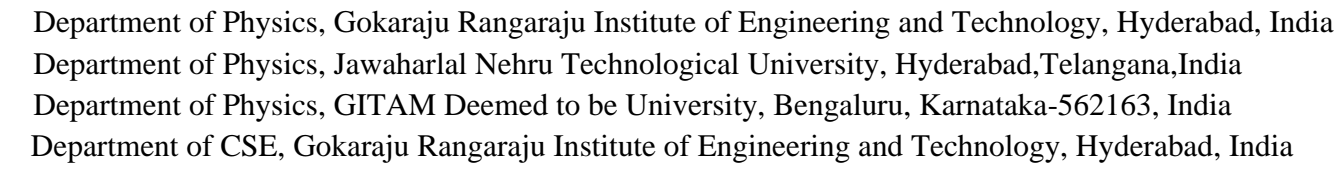

Received: 14.04.2021; Revised: 10.06.2021; Accepted: 15.06.2021; Published: 27.06.2021

\begin{abstract}
In this present study, Tin doped $\mathrm{In}_{2} \mathrm{O}_{3}$ metal oxide was synthesized by green synthesis using almond gum as a reducing agent. The prepared Nanocomposite (Ncs) was characterized by TG-DTA, XRD, SEM, EDX, FTIR, and UV-Vis spectroscopy. From TG-DTA able to get some information regarding calcination temperature. This was found out to be over $300{ }^{\circ} \mathrm{C}$. The XRD study revealed that the $\mathrm{In}_{2} \mathrm{O}_{3}-\mathrm{SnO}_{2}$ nanocomposite with crystal size $13 \mathrm{~nm}$ to $16 \mathrm{~nm}$. The SEM study revealed that the morphology of prepared nanocomposite is Cubic phased sphere structure, and EDAX data show that elements in the composite of $\mathrm{In}_{2} \mathrm{O}_{3}-\mathrm{SnO}_{2}$ are $\mathrm{O} 74.71 \%$, In $23.45 \%$, and $\mathrm{Sn} 1.84 \%$. FT-IR spectra confirm the formation of the In-O-In and Sn-O-Sn type of bonding. The UV-Vis spectra imply the bandgap of generated $\mathrm{In}_{2} \mathrm{O}_{3-} \mathrm{SnO}_{2} \mathrm{Ncs}$ is $3.83 \mathrm{ev}$.
\end{abstract}

Keywords: Nanocomposites; Metal oxides; Nanoparticles; synthesis; thermal analysis

(C) 2021 by the authors. This article is an open-access article distributed under the terms and conditions of the Creative Commons Attribution (CC BY) license (https://creativecommons.org/licenses/by/4.0/).

\section{Introduction}

When brought down to nano-size, the materials have a large surface-to-volume ratio, which creates innovative properties. Among nanoparticles, metal oxide Ncs have consequential attention due to their electrical, optical, magnetic, and catalytic properties [1]. Most studies have relied on a wide range of metal-oxides Ncs applications as catalytic application [2], electrochemical energy storage [3], and gas sensing [4]. Recently GO@ $\mathrm{TiO}_{2} \mathrm{Ncs}$ examined toxic insecticides in water [5], reduced graphene oxide shows solar cell device with photoconversion efficiency [6]. Several methods are used for the synthesis of metal oxide Ncs, such as polymerization [7], sol-gel [8-13], one-pot solvothermal [14], and physical vapor deposition [15].

In response, researchers are now looking for an alternative "green synthesis" approach by which they can produce low-toxic, low-cost synthesis and environmentally friendly. Tree gums are essential natural, renewable sources for the green synthesis of nanoparticles suitable for reducing and capping agents. Besides, I. Syed et al. analyze the prospect of using almond 
gum to synthesize hydro gel-silver Ncs by free radical polymerization method, which is costeffective and non-toxic [16]. Thus, in this investigation, we initiated our exploration using almond gum as a Plant-Derived biopolymer to synthesize $\mathrm{In}_{2} \mathrm{O}_{3}-\mathrm{SnO}_{2} \mathrm{Ncs}$. Almond gum is one of the natural polymers exuded from the trunk of the almond tree (Purnisdulcis).

$\mathrm{In}_{2} \mathrm{O}_{3}$ is an n-type nanostructured transparent semiconductor oxide and has been interpreted as a direct bandgap of (3.5-3.7eV). It exhibits high electrical conductivity; high sensitivity. It has been successfully employed in several modern electronic devices. Further to stimulate the properties of $\operatorname{In}_{2} \mathrm{O}_{3}$, it is fine-tuned by a suitable dopant. As $\mathrm{SnO}_{2}$ is good sensing material, good stability, and low cost; hence, the doping of $\mathrm{SnO}_{2}$ into $\mathrm{In}_{2} \mathrm{O}_{3}$ can be investigated with interesting properties $[17,18]$. Sn-doped indium oxide is the most eminent transparent conducting oxide material with diverse applications such as solar cells, liquid crystal lenses, and ammonia sensing [19-21]. However, $\mathrm{In}_{2} \mathrm{O}_{3}-\mathrm{SnO}_{2} \mathrm{Ncs}$ is an excellent biosensor because of its low light absorption and fine electrical conductivity [22]. The present study studied the green synthesis of $\mathrm{In}_{2} \mathrm{O}_{3}-\mathrm{SnO}_{2} \mathrm{Ncs}$ using an almond gum eco-friendly approach, which serves as stabilization and bioreduction for synthesized Ncs.

\section{Materials and Methods}

\subsection{Chemicals used.}

In(acac) 3 and Tin(IV) bis (acetylacetonate) dichloride were procured from Sigma Aldrich, Almond gum was purchased from local market Hyderabad.

\subsection{Green synthesis of $\mathrm{In}_{2} \mathrm{O}_{3-} \mathrm{SnO}_{2}$ nanocomposite.}

$\mathrm{In}_{2} \mathrm{O}_{3}-\mathrm{SnO}_{2}$ nanocomposite was synthesized, making use of $\mathrm{In}(\mathrm{acac})_{3}(0.75 \mathrm{gm}), \mathrm{Tin}(\mathrm{IV})$ bis(acetylacetonate) dichloride $(0.25 \mathrm{gm})$, almond gum $(0.125 \mathrm{gm})$, and was ground to a fine powder by using motor and pestle. The method of preparation has been given in Figure 1. The precursors were characterized through thermogravimetric-differential thermal analysis (TGDTA) to determine the decomposition and temperature change. As the calcination temperature was found to be above $350{ }^{\circ} \mathrm{C}$, the precursors are calcined in a muffle furnace at $500{ }^{\circ} \mathrm{C}$ for 2 hours in the air. After calcination, the color of the mixture turnover to pale yellow color, a confirmation for Indium tin oxide nanocomposite formation.

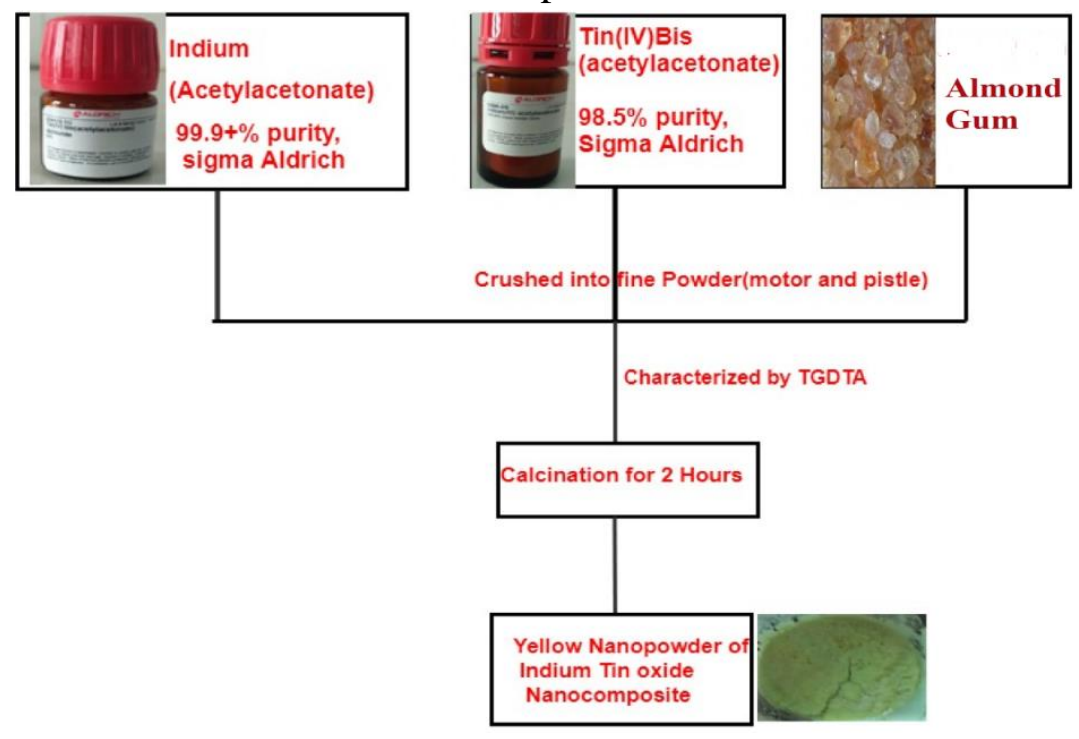

Figure 1. Flow chart for the synthesis of $\mathrm{In}_{2} \mathrm{O}_{3}-\mathrm{SnO}_{2} \mathrm{Ncs}$. 
The obtained $\mathrm{In}_{2} \mathrm{O}_{3}-\mathrm{SnO}_{2}$ nanopowder was characterized by X-ray diffractometer (XRD) with $\mathrm{Cu} \mathrm{K} \alpha$ radiation, SEM, and composition recognized the morphology by EDAX, the UV-Vis absorption spectrum is used to evaluate the bandgap of prepared Ncs. The Fouriertransform infrared (FT-IR) analysis was carried out on a spectrophotometer to identify the surface structure of $\mathrm{In}_{2} \mathrm{O}_{3}-\mathrm{SnO}_{2} \mathrm{Ncs}$ in the wavelength range of $4000-400 \mathrm{~cm}^{-1}$.

\section{Results and Discussion}

\subsection{TG-DTA analysis.}

The thermal analysis and decomposition of synthesized $\mathrm{In}_{2} \mathrm{O}_{3}-\mathrm{SnO}_{2} \mathrm{Ncs}$ were calculated by thermogravimetric-differential analysis. Thermal analysis curves are shown in Figure 2. The TG curve shows significant weight loss from $100{ }^{\circ} \mathrm{C}$ to $300{ }^{\circ} \mathrm{C}$, and some extent, $300{ }^{\circ} \mathrm{C}$ to $600{ }^{\circ} \mathrm{C}$ and further no more weight loss are observed. The DTA curve shows the decomposition behavior between $200{ }^{\circ} \mathrm{C}$ to $450{ }^{\circ} \mathrm{C}$, and a main exothermic peak was observed at $350{ }^{\circ} \mathrm{C}$.

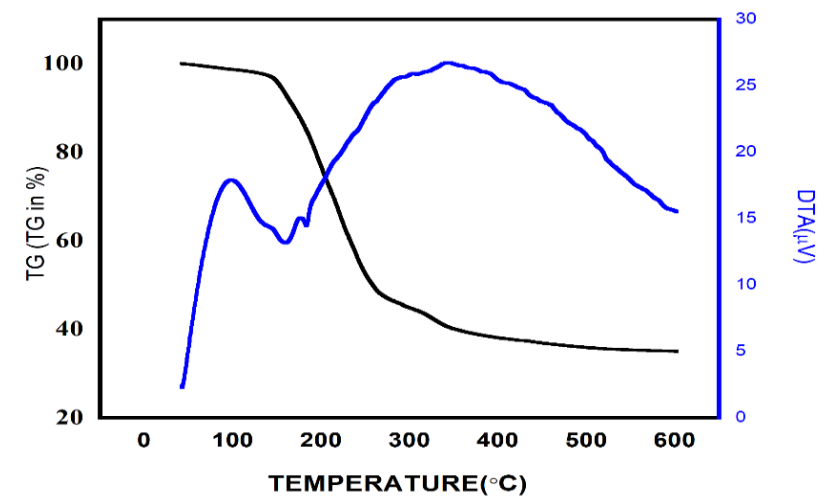

Figure 2. TG-DTA curves of thermal analysis of $\operatorname{In}_{2} \mathrm{O}_{3}-\mathrm{Sno}_{2} \mathrm{NCs}$.

\subsection{XRD analysis.}

The XRD spectra of calcined $\mathrm{In}_{2} \mathrm{O}_{3}-\mathrm{SnO}_{2}$ nanopowder have been given in Figure 3. It can be seen from the figure that the crystallinity of Nc and the peaks at (211), (222), (400), (431), (440), (622), and (631) confirm the formation of cubic bixbyite structure (JCPDS 060416) and no other impurity peaks were detected.

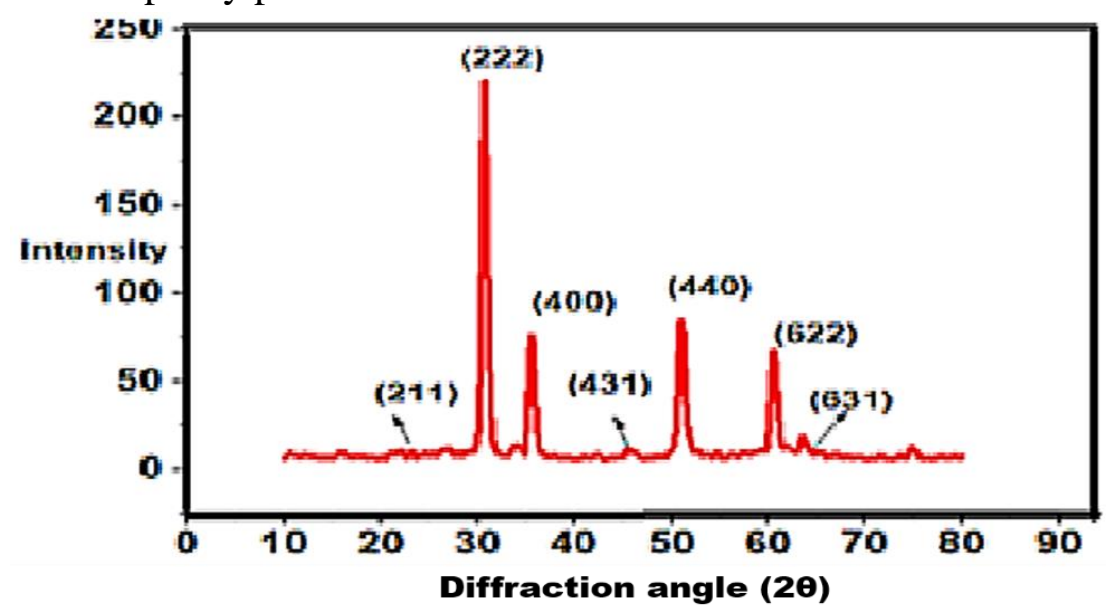

Figure 3. XRD pattern of $\mathrm{In}_{2} \mathrm{O}_{3}-\mathrm{SnO}_{2}$ nanocomposite calcined in air for 2 hours at $500{ }^{\circ} \mathrm{C}$.

\subsection{SEM analysis.}


The average crystal size of Ncs was determined by Scherer's equation $\mathrm{d}=\frac{\mathrm{k} \lambda}{\beta \cos \theta}$, where $\mathrm{d}$ is particle size, $\lambda$ is $\mathrm{X}$-ray wavelength, and $\mathrm{k}$ is constant $(0.89), \beta$ is full width half maximum, and crystal size was found to be $13 \mathrm{~nm}$ to $16 \mathrm{~nm}$. The broadening of XRD peaks can be assigned to the size of the nanoparticle. At the same time, strong and narrow peaks illustrate that the NCs have good crystallinity.

The surface morphology of synthesized $\mathrm{In}_{2} \mathrm{O}_{3}-\mathrm{Sno}_{2} \mathrm{Ncs}$ was investigated by SEM analysis. Figure 4 shows SEM images of $\mathrm{In}_{2} \mathrm{O}_{3}-\mathrm{SnO}_{2} \mathrm{Ncs}$ having uniform surface morphology in a spherical shape with fine crystallites having a size in the range of 98.17-133 nm [23]. These images show that synthesized Ncs were highly uniform distributed.
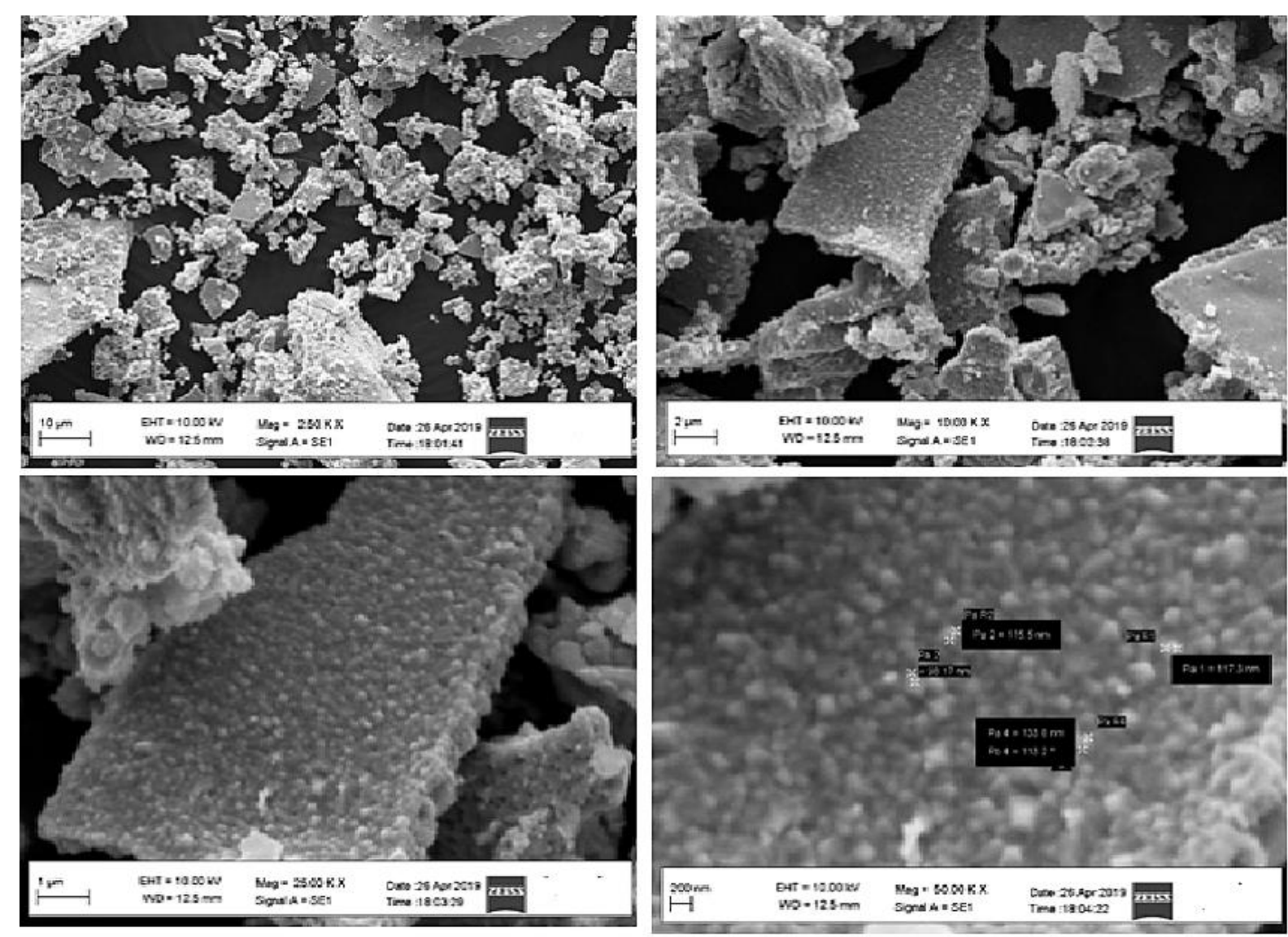

Figure 4. SEM pattern of $\mathrm{In}_{2} \mathrm{O}_{3}-\mathrm{SnO}_{2}$ Nanocomposite calcined in air for 2 hours at $500{ }^{\circ} \mathrm{C}$.

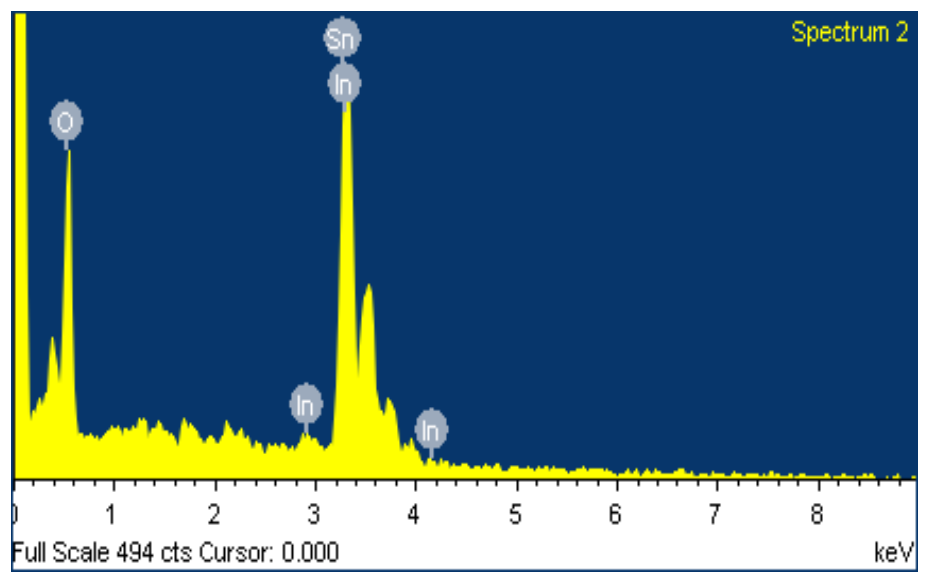

\begin{tabular}{|l|l|l|}
\hline Element & Weight\% & Atomic\% \\
\hline O K & 29.11 & 74.71 \\
\hline In L & 65.58 & 23.45 \\
\hline Sn L & 5.32 & 1.84 \\
\hline Totals & 100 & 100 \\
\hline
\end{tabular}

Figure 5. EDX analysis of $\mathrm{In}_{2} \mathrm{O}_{3}-\mathrm{SnO}_{2}$ nanocomposite. 


\subsection{EDX analysis.}

The chemical composition of the prepared nanocomposite was studied using EDX analysis, and the study revealed that the nanocomposite is nearly stoichiometric. The composition of all the elements in $\mathrm{In}_{2} \mathrm{O}_{3}-\mathrm{SnO}_{2} \mathrm{Ncs}$ is $\mathrm{In}(65.58 \%), \mathrm{O}(29.11 \%)$, and $\mathrm{Sn}(5.32 \%)$ based on atomic \% analysis. Figure 5 illustrates peaks comparable to In, Sn, and O elements. The nanocomposite is almost pure as no additional impurities were observed. The existence of $\mathrm{In}, \mathrm{Sn}$, and $\mathrm{O}$ confirms the formation of $\mathrm{In} / \mathrm{SnNcs}$.

\subsection{FTIR.}

Figure 6 exhibits the absorption band at 3471 and $1682 \mathrm{~cm}^{-1}$ represents stretching peaks and bending vibration of $-\mathrm{OH}$, respectively. Moreover, peaks at 2359 and $1483 \mathrm{~cm}^{-1}$ are affiliated with $\mathrm{CH}$ bending vibrations. The peak at $1132 \mathrm{~cm}^{-1}$ is attributed to the stretching vibration of $\mathrm{C}-\mathrm{OH}$ bond, correspondingly broad bands at $2999 \mathrm{~cm}^{-1}$ and $2359 \mathrm{~cm}^{-1}$ can be related to $\mathrm{O}-\mathrm{H}$ stretching and bending vibration, considering water molecule absorbed at the surface.

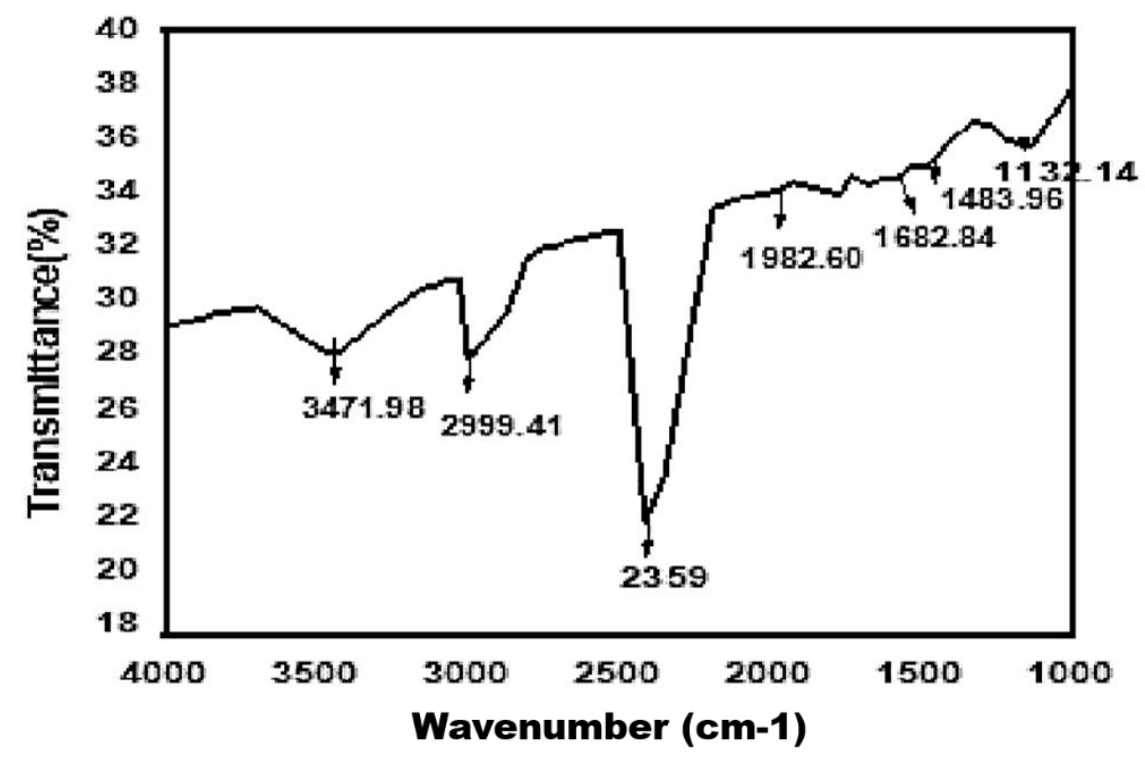

Figure 6. FTIR spectrum of $\mathrm{In}_{2} \mathrm{O}_{3}-\mathrm{SnO}_{2}$ nanocomposite.

\subsection{UV-Vis spectra.}

The prepared sample's optical property and bandgap energy was observed using UVVis spectra analysis. In the UV-Vis, a characteristic absorption peak of the $\mathrm{In}_{2} \mathrm{O}_{3}-\mathrm{SnO}_{2}$ sample exhibits a strong peak at $310 \mathrm{~nm}$, which implies the formation of $\mathrm{In}_{2} \mathrm{O}_{3}-\mathrm{SnO}_{2} \mathrm{Ncs}$ calcined in air at $500{ }^{\circ} \mathrm{C}$. The spectra are as shown in Figure 7(a). The intensity of the sharp peak confirms the absorption of $\mathrm{In}_{2} \mathrm{O}_{3}-\mathrm{SnO}_{2}$ due to the particle's surface Plasmon resonance. Figure 7(b) represents the Tauc's plot of $\mathrm{In}_{2} \mathrm{O}_{3}-\mathrm{SnO}_{2} \mathrm{Ncs}$ obtained from direct optical bandgap by plotting $\alpha v^{2}$ versus ho(photon energy) applying Tauc'srelation [24].

$$
\alpha h v=\alpha_{0}(\mathrm{~h} v-\mathrm{Eg})^{1 / 2}
$$

where ho, $\alpha_{0}$ and Eg is photon energy, constant and optical band gap of Ncs, and bandgap energy was obtained through extrapolating the linear portion, energy bandgap (Eg) calculated for $\mathrm{In}_{2} \mathrm{O}_{3}-\mathrm{SnO}_{2} \mathrm{Ncs}$ is $3.83 \mathrm{eV}$. 

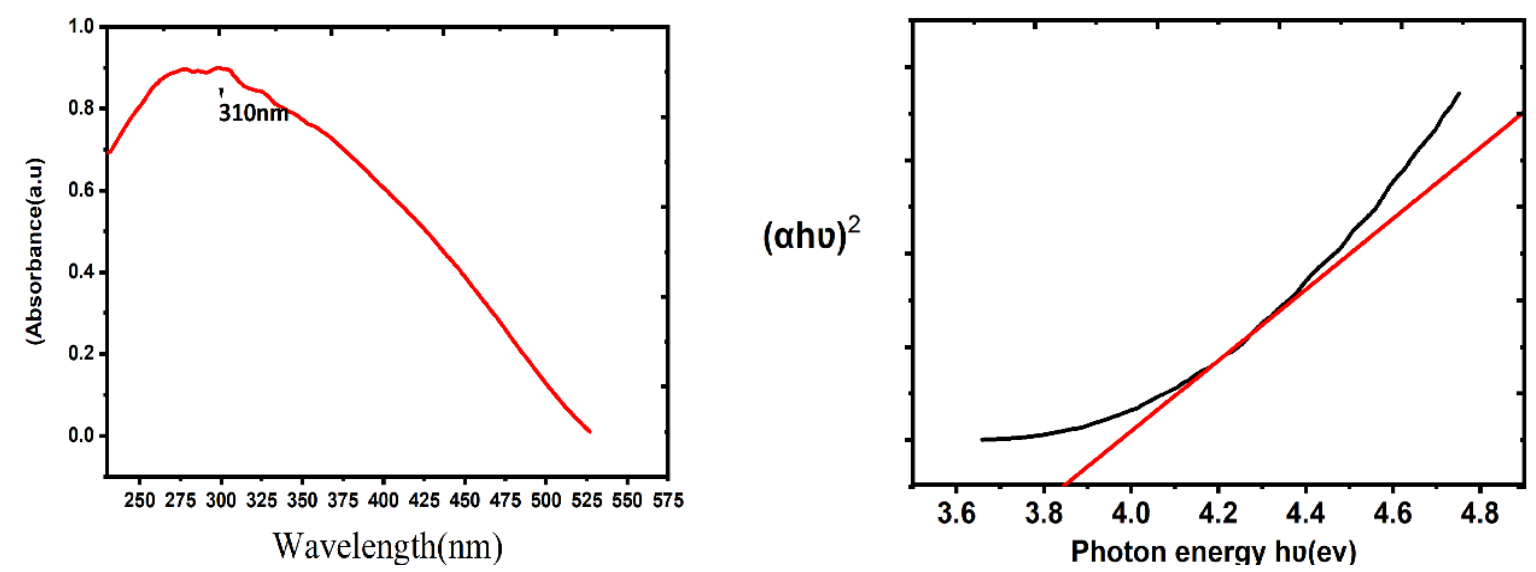

Figure 7. (a) UV-Visible spectra; (b) energy bandgap of $\mathrm{In}_{2} \mathrm{O}_{3}-\mathrm{SnO}_{2}$ nanocomposite.

\section{Conclusions}

This paper has noted the synthesis of $\mathrm{In}_{2} \mathrm{O}_{3}-\mathrm{SnO}_{2} \mathrm{Ncs}$ by almond gum through the green method. XRD data confirm that the $\mathrm{In}_{2} \mathrm{O}_{3}-\mathrm{SnO}_{2}$ are cubic bixbyite structures with particle size $13-16 \mathrm{~nm}$, TG/DTA produce that the weight loss was $1 \%$, affirming that the sample is high purity. The morphology is showing the sample to be spherical by scanning electron microscopy images. EDX displays the chemical composition of $\mathrm{In}_{2} \mathrm{O}_{3}-\mathrm{SnO}_{2} \mathrm{Ncs}$. Based on FTIR characterization, spectra confirm the formation of In-O-In and Sn-O-Sn types of bonding. The optical properties have been studied by ultraviolet-visible (UV-Vis) spectroscopy which exhibits a strong peak at $310 \mathrm{~nm}$, and the bandgap by UV-Vis Tauc's method was found to be $3.83 \mathrm{eV}$.

\section{Funding}

This research received no external funding.

\section{Acknowledgments}

The authors are grateful to Chairman GRIET Hyderabad for support the research.

\section{Conflicts of Interest}

The authors declare no conflict of interest.

\section{References}

1. Dubey, S.; Kumar, J.; Kumar, A.; Sharma, Y.C. Facile and green synthesis of highly dispersed cobalt oxide $\left(\mathrm{Co}_{3} \mathrm{O}_{4}\right)$ Nano powder: Characterization and screening of its eco-toxicity. Adv.Pow. Tech.2018, 29, 25832590,https://doi.org/10.1016/j.apt.2018.03.009.

2. Owonubi, S.J.; Malima, N.M.; Revaprasadu, N. Chapter 16 - Metal Oxide-Based Nanocomposites as Antimicrobial and Biomedical Agents, Editor(s): Varaprasad Kokkarachedu, Vimala Kanikireddy, Rotimi Sadiku, Antibiotic Materials in Healthcare, Academic Press, 2020, Pages 287-323, ISBN 9780128200544, https://doi.org/10.1016/B978-0-12-820054-4.00016-1.

3. Rani, M.; Shanker, U.Sun-light driven rapid photo catalytic degradation of methylene blue by poly(methyl methacrylate)/metal oxide nanocomposites. Colloids Surf. A Physicochem. Eng. Asp. 2018, 559, 136147,https://doi.org/10.1016/j.colsurfa.2018.09.040.

4. Immanuel, S.; Aparna, T. K.; Sivasubramanian, R.Graphene-Metal Oxide Nanocomposite Modified Electrochemical Sensors. In Graphene-Based Electrochemical Sensors for Biomolecules, Elsevier, 2019, 113-138,https://doi.org/10.1016/B978-0-12-815394-9.00005-4. 
5. Garcia, C. V.; Shin, G. H.; Kim, J. T. Metal oxide-based nanocomposites in food packaging: applications, migration, and regulations. Trends Food Sci. Technol. 2018, 82, 2131.https://doi.org/10.1016/j.tifs.2018.09.021.

6. Jiang, H.; Ma, J.; Li, C. Mesoporous Carbon Incorporated Metal Oxide Nanomaterials as Super Capacitor Electrodes. Adv.Mat. 2012, 24, 4197-4202, https://doi.org/10.1002/adma.201104942.

7. Wang, D.; Kou, R.; Choi, D.; Yang, Z.; Nie, Z.; Li, J.; Saraf, L. V.; Hu, D.; Zhang, J.; Graff, G. L.; Liu, J.; Pope, M. A.; Aksay I. A. Ternary Self-Assembly of Ordered Metal Oxide-Graphene Nanocomposites for Electrochemical Energy Storage ACS Nano 2010, 4, 1587-1595,https://doi.org/10.1021/nn901819n.

8. Moshnikov, V.A.; Gracheva, I.; Lenshin, A.S.; Spivak, Y.M.; Anchkov, M.G.; Kuznetsov, V.V.; Olchowik, J.M.; Porous silicon with embedded metal oxides for gas sensing applications.J. Non-Cryst.Solids 2012, 358, 590-595,https://doi.org/10.1016/j.jnoncrysol.2011.10.017.

9. Shaheen, K.; Shah, Z.; Khan, B.; Adnan, Omer, M.; Alamzeb, M.; Suo H. Electrical, photocatalytic, and humidity sensing applications of mixed metal oxide nanocomposites. ACS Omega 2020, 5, 72717279,https://doi.org/10.1021/acsomega.9b04074.

10. Razavi, F.S.; Sobhani, A.; Amiri, O.; Ghiyasiyan-Arani, M.; Salavati-Niasari, M. Green sol-gel autocombustion synthesis, characterization and investigation of the electrochemical hydrogen storage properties of barium cobalt oxide nanocomposites with maltose. Int. J. Hydrog. Energy, 2020, 45, 17662-17670, https://doi.org/10.1016/j.ijhydene.2020.04.273.

11. El Nahrawy, A.M.; Abou Hammad, A.B.; bakr, A.M.; Shaheeen, Th.I.; Mansour, A.M. Sol-gel synthesis and physical characterization of high impact polystyrene nanocomposites based on $\mathrm{Fe}_{2} \mathrm{O}_{3}$ doped with $\mathrm{ZnO}$. Appl. Phys. A, 2020, 126, https://doi.org/10.1007/s00339-020-03822-w.

12. Dippong, T.; Cadar, O.; Levei, E.A.; Deacc, I.G. Microstructure, porosity and magnetic properties of $\mathrm{Zn}_{0.5} \mathrm{Co}_{0.5} \mathrm{Fe}_{2} \mathrm{O}_{4} / \mathrm{SiO}_{2}$ nanocomposites prepared by sol-gel method using different polyols. J. Magn. Magn. Mater. 2020, 498, 166168, https://doi.org/10.1016/j.jmmm.2019.166168.

13. Ravishankar, T.N.; Vaz, M.de.O.; Teixeirab, S.R. The effects of surfactant in the sol-gel synthesis of $\mathrm{CuO} / \mathrm{TiO}_{2}$ nanocomposites on its photocatalytic activities under UV-visible and visible light illuminations. New J. Chem., 2020, 44, 1888-1904, https://doi.org/10.1039/C9NJ05246A.

14. El-Shafai, N.M.; El-Khouly, M.E.; El-Kemary, M.; Ramadan, M.S.; Derbalah, A.S.; Masoud, M.S. Fabrication and characterization of graphene oxide-titanium dioxide nanocomposite for degradation of some toxic insecticides. J. Ind. Eng. Chem. 2019, 69, 315-323, https://doi.org/10.1016/j.jiec.2018.09.045.

15. Johny,J.; Sepulveda-Guzman, S.; Krishnan,B.; Avellaneda,D.A.; Martinez, J.A.A.; Anantharaman,M.R.; Shaji,S.Tin sulfide: Reduced graphene oxide nanocomposites for photovoltaic and electrochemical applications.Sol.Energy Mater.Sol. Cells 2019, 189, 53-62, https://doi.org/10.1016/j.solmat.2018.09.025.

16. Zhu, C-L.; Chou, S-W.; He, S-F.; Liao W-N.; Chen, C-C. Synthesis of core/shell metal oxide/polyanilinenanocomposites and hollow polyanilinecapsules, Nanotechnology 2007, 18, 275604, https://doi.org/10.1088/0957-4484/18/27/275604.

17. Wang, G.; Yang, Z.; Li, X.; Li, C. Synthesis of poly(aniline-co-o-anisidine)-intercalated graphite oxide composite by delamination/reassembling method. Carbon 2005, 43, 2564-2570, https://doi.org/10.1016/j.carbon.2005.05.008.

18. Clapsaddle, B.J.; Gash, A.E.; SatcherJr., J.H.; Simpson, R.L. Silicon oxide in an iron(III) oxide matrix: the sol-gel synthesis and characterization of $\mathrm{Fe}-\mathrm{Si}$ mixed oxide nanocomposites that contain iron oxide as the major phase. J. Non-Cryst. Solids 2003, 331, 190-201, https://doi.org/10.1016/j.jnoncrysol.2003.08.068.

19. Gao, B.; Chen, G.Z.; Puma, G.L.Carbon nanotubes/titanium dioxide (CNTs/TiO 2 ) nanocomposites prepared by conventional and novel surfactant wrapping sol-gel methods exhibiting enhanced photocatalytic activity. Appl.Catal. B. 2009, 89, 503-509, https://doi.org/10.1016/j.apcatb.2009.01.009.

20. Ye, L.; Fu, Z.; Xu, Z.; Yuan, R.; Li, Z. Facile One-Pot Solvothermal Method to Synthesize Sheet-on-Sheet Reduced Graphene Oxide (RGO)/ZnIn $\mathrm{S}_{4}$ Nanocomposites with Superior PhotocatalyticPerformance.ACS Appl. Mater. Interfaces 2014, 6, 3483-3490, https://doi.org/10.1021/am5004415.

21. Richter, K.; Birkner, A.; Mudring, A-V.Stabilizer-Free Metal Nanoparticles and Metal-Metal Oxide Nanocomposites with Long-Term Stability Prepared by Physical Vapor Deposition into Ionic Liquids.Angew. Chem. Int. Ed. Engl. 2010, 49, 2431-2435, https://doi.org/10.1002/anie.200901562.

22. Hussain, I.S.A.; Jaisankar,V.; An eco-friendly synthesis, characterization and antibacterial applications 2 of novel almond gum - poly(acrylamide) based hydrogel silver nanocomposite. Polym.Test. 2017, 62, 154-161, https://doi.org/10.1016/j.polymertesting.2017.06.021. 
23. Bierwagen, O. Indium oxide - A transparent wide-band gap semiconductor for (opto)electronic applications. Semicond.Sci.Technol. 2015, 30, 024001, http://dx.doi.org/10.1088/0268-1242/30/2/024001.

24. Boppella, R.; Manjula, P.; Arunkumar, S.; Manorama, S.V.; Advances in synthesis of nanostructure metal oxides for chemical sensors. Chem. Sen. $2014, \quad 4, \quad$ 1-22, http://www.cognizure.com/abstract.aspx?p=200638362. 